\title{
Promoting Women's Entrepreneurship through SME: Growth and Development in the context of Bangladesh
}

\author{
Afiya Sultana \\ * Lecturer, Faculty of Business Administration, University of Science and Technology Chittagong, Post Box- \\ 1079, Chittagong, Bangladesh.
}

\begin{abstract}
Women's entrepreneurship is an inevitable part of country's economic development process. The main objective of this study is to having an overview of women entrepreneurs in Bangladesh and growth situation through SME. The issue covered by this study are socio-demographic profile of women entrepreneur, types of women owned entrepreneur, regulatory procedures, training and capacity building and human resources development through women's empowerment. The study also focused on role of SME to promoting women entrepreneurs. It also explores the social perspective of women entrepreneurs as well as the impact of these entrepreneurs on the economic development of Bangladesh.

Both qualitative and quantitative research methods adapting with primary data collection process were applied to explore information from sample unit of women entrepreneur of Chittagong region in Bangladesh. A semi structured questionnaire survey was conducted to collect primary data. Data were analyzed using various statistical software including SPSS, MS Excel.

The findings shows that women's entrepreneurship of Bangladesh is growing at accelerate rate and their contribution to socio- economic development is significant. It is observed that $62.5 \%$ of the respondents took the SME loan to establish and run their business smoothly. This study found some problems facing by women's entrepreneur of Bangladesh.

The paper made an analytical framework to analyze the factors relating to problem and development issue in used institutional theory. This study found some problems facing by women's entrepreneur of Bangladesh. This study also suggested some policy and their possible implications for improving women entrepreneurship so that they can make contribution to the economic development process.

Key-Words: Women Entrepreneurship; SME, Economic Development.
\end{abstract}

\section{Introduction}

Bangladesh is a resource based country both natural and human but overpopulated where society is highly stratified in gender and class based. From the year of early 1990s, including Bangladesh the developing countries of the world have been focused attention on the development of women entrepreneurship. However, women make nearly $50 \%$ of the total population structure ${ }^{11}$, which means huge potential to be utilized for socioeconomic development of the country. Due to the de18mographic structure, the issue of the participation of women in the mainstream economy is crucial. It is also impossible to achieve the target of poverty free society and achieving the millennium goals without incorporation of women in the income generating activates. Considering the issue, a special emphasis has been given by the Government, donor agencies, NGOs, business community and all other relevant stakeholders through various initiatives to ensure women's participation in business and industry.

Majority of women in Bangladesh are not only poor but also stiffed between the world that determined by culture and tradition to engaging themselves in the activities of homesteads that keep them outside into various economic activities. For those cultural barriers- despite various initiatives from different corner, the level of participation of women in the mainstream economic activities remains insufficient and the percentage of women participation in business and industry is still below than that of their male counterpart. Although women have now become aware of their socio-economic rights and have ventured to avail the opportunities and take challenge to develop themselves in business activities.

It is inspiring to mention here that, now a day more women interested to establish their own business as professionally both in the urban and rural areas due to overcome poverty, generate family income and increasing standard of living. This is because access of capital, funding capital through SME loan, and other supportive program by government and others concerning body. On the other hand, some women have taken up women

\footnotetext{
${ }^{1}$ Sources: Statistical Pocketbook, Bangladesh 10', Bangladesh Bureau of Statistics, Government of the Peoples Republic of Bangladesh, Dhaka, 2010.
} 
Promoting Women's Entrepreneurship through SME: Growth and Development in the context of entrepreneurship not necessarily to earn and survive but to form their careers and become professionals in order to contribute towards the progress of the society and nation.

\section{Objectives Of The Study}

Following are the objectives of the study to find out ways and means how to developed women entrepreneurship in Bangladesh:

- To analyze present scenario of women entrepreneurship in Bangladesh including profile and types of women-owned enterprises

- Examine the extent of SME for women entrepreneur and ensure women's participation in economic development of the society

- Support women entrepreneurs to grow and develop from micro to small and medium enterprise and so on

- Train and promote skill of women entrepreneurs including potential women entrepreneurs.

- To create awareness of society and lobby with the government for creating enabling environment for women entrepreneurs and potential entrepreneurs.

- Social and institutional perspective of women entrepreneurs.

- Find out the problem and challenge that have faced by women entrepreneurs in Bangladesh.

- Construct possible recommendation and guidelines to overcome the problem and facilitate to women entrepreneurs.

\section{Methodology Adopted}

It is sample survey constituted 40 women entrepreneur as sample unit from Chittagong Metropolitan area. A set of questionnaires (Annex 1) were distributed among the women entrepreneurs for collecting data about development of enterprises, about SME facility and views about problems and prospect of women entrepreneurs. The participants were also asked to propose what should be done to support them. For relevant secondary data from CCCI, CWCCI, Publication from Finance Ministry, MIDAS, BSCIC, WEA, WEAB and DCCI was collected that include, among others, project documents, evaluation reports, survey and study papers, training and workshop materials, statistics, etc. Besides, relevant World Bank and UNDP publications and Study Papers (if any) on Bangladesh and other similar countries (if any) was collected. At the end, the collected secondary materials were sorted, studied, analyzed and evaluated. Finally, on the basis of the analysis and findings of the secondary materials and primary data, suggestions for national policy reforms and implications, financial promotional program and extended the SME opportunity and technical support (training, workshop, counseling, consulting, etc) have to stated. The study, in fact, follows the method of descriptive analysis on related issue of women entrepreneur and development issue in the context of Bangladesh. It analyses first the social and economic status of the women in the country, then it studies the weakness and strength of the existing service providing public and private sector organizations, institutions and agencies. After that it finds out the problems and opportunities, which must be reduced and extended the related services and utilized for the sake of the development of the society as a whole.

\section{Literature Review}

A good number of studies have been done on entrepreneurship in Bangladesh. Habibullah (1987) showed that training is an effective tool for entrepreneurship development in Bangladesh. Habibur Rahman (1995) emphasized the importance of project viability, collateral and entrepreneurial evaluation at the project appraisal level of banks. Saleh (1999) found inadequate cash flows, marketing deficits and discriminating treatment from supportive service agencies to create obstacles to women entrepreneurship development in Bangladesh. Rahman (1999) examines women borrowers' involvement with the microcredit program of the Grameen Bank, and the grassroots lending structure of the bank. He focuses on the processes of village-level microcredit operation and addresses the realities of the day-to-day lives of women borrowers and bank workers and explains informant strategies for involving themselves in this microcredit scheme. Aktaruddin (1999) showed that personal attributes are key factors for entrepreneurial success or failure, while Aktaruddin (2000) focused on the social-economic background of the entrepreneurs. Masuda (2001) showed that extensively different types of business were established by women entrepreneur of Bangladesh. Momen and Begum (2006) measured the impact BRAC's micro credit program had for the development of rural women entrepreneurship. Afrin, Islam and Ahmed (2008) aimed at identifying the factors related to the development of entrepreneurship among the women borrowers through micro credit programs. Using a multivariate analysis, they showed that financial management skills and the group identity of the women borrowers have significant relationship with the development of rural women entrepreneurship in Bangladesh. Huda (2009) examine that women entrepreneur of Bangladeshi engaging both formal and informal sector of economy and have growing interest of them to extend their business commercially. Most recently, Bangladesh Women Chamber of Commerce and 
Promoting Women's Entrepreneurship through SME: Growth and Development in the context of Industry (BWCCI) 2008 made an extensive analysis as a case study on women entrepreneurs in Bangladesh, which was the country's first trade body working exclusively for women's economic and social empowerment.

\section{Concept Of Women Entrepreneurship And Sme}

Increase in cost of living has prompted the society's women to undertake economic activities in order to support their families. They are coming forward to take risks, face challenges and prove to the world that their role in the society is no more limited to that of buyers but they can be also successful sellers and traders. There are thousands of good examples where women have shown entrepreneurial talents and have succeeded. Women entrepreneurs are the key players in any developing country in terms of their contribution to economic development. In the simplest sense, women entrepreneurs are those women who take the lead and organize the business or industry and provide employment to others. It signifies that section of female population who venture out into industrial activities. It may be defined as a woman or group of women who initiate, organize and run a business enterprise.

However, Government has given a broader definition of the term women entrepreneur. It defined women entrepreneur as "an enterprise owned and controlled by women having a minimum financial interest of $51 \%$ of the capital and giving at least $51 \%$ of the employment generated in the enterprise to women".

According to J.A. Schumpeter, "Woman who innovates, imitates, or adopts a business activity is called woman entrepreneur." Thus women entrepreneur are those women who initiate, organize and operate business enterprise and want to prove their mettle in innovative and competitive jobs. She also wants to oversee and control every aspects of her business for its overall success. Today, SME remains the engine of economic growth and considering the population of Bangladesh, SME offers large-scale employment and income earning opportunities at relatively low costs, especially in the rural areas. It strengthens efforts to achieve high and sustainable growth, which is a prerequisite for an exit from widespread poverty and socio-economic deficit.

In the convergence of growth in SME, women entrepreneurship plays a pivotal role. The obligations of society towards such events remain unattended and incomplete. The central bank has come up with a new definition for small and medium enterprises in line with the government's industrial policy of 2010. Also, the move also defines the country's growing women entrepreneurs for the first time. Under the new definition, the Bangladesh Bank will deem a woman as an entrepreneur if the person is an owner or proprietor of a privatelyrun organization, or owns at least 51 percent of share in case of a joint venture or company listed with the Office of the Registrar of Joint Stock Companies and Firms.

The central bank also included micro enterprise and cottage industries in all of its SME loan policies and programmes. The official said the definition of 'women entrepreneurs' aims to acknowledge their contribution to the economy. "It's actually an effort for gender mainstreaming in business. It will help remove confusion among financial institutions about who is a woman entrepreneur and who is not." As a result, the government will be able to hand out incentives to women entrepreneurs effectively and promote them. In Bangladesh, the SMEs account for about 45 percent of manufacturing value addition, 80 percent of industrial employment, 90 percent of total industrial units and about 25 percent of total labour force. Their total contribution to export earnings ranges from 75 percent to 80 percent, according to a recent economic census. The SMEs make up 75 percent of the domestic economy. There are about 60 lakh SMEs and micro enterprises in Bangladesh, according to Asian Development Bank.

According to the new definition, in case of manufacturing, a medium-size industry/enterprise will be those with assets worth Tk 10 crore to Tk 30 crore (excluding land and factory building, but including replacement value) or 100 to 250 workers. In both services industry and businesses, the medium enterprises will be those which employ 50 to 100 workers and have assets worth Tk 1 crore to Tk 15 crore (excluding land and factory building).

\subsection{Growth of women entrepreneurship in last two decades}

According to the Bangladesh's demographic structure the total population consists of $50 \%$ women. But they constitute a very negligible proportion of the total entrepreneurs only $10 \%$ of the total business entrepreneur in Bangladesh. Entrepreneurial traits and competencies have not been well developed amongst the women entrepreneurs. They are the neglected sections in the society. The much low literacy rate $31.8 \%$, low work participation rate $26 \%$ and low urban population share $10 \%$ of women as compared to $53.9 \%$, and $54 \%$ respectively of their male counterpart well confirm their precarious position in the society.

It is heartening to note that despite many barriers, a new women's entrepreneur class has arisen in the country taking on the challenge to work in a male-dominated, competitive economic and business environment. Bangladeshi women started their entrepreneurial work in 1970s. Women have started entrepreneurial activities as one- woman enterprises at home and from home for self-occupation and engagement. The numbers of women entrepreneurs were only 6000 in Chittagong division which measured by Chittagong Women Chamber of Commerce and Industry and they also informed that growth rate of women entrepreneur by year as 
Promoting Women's Entrepreneurship through SME: Growth and Development in the context of approximately 56\%. That indicates, women are encouraged to start an occupation or venture with an urge to do something independently started to tide over their economic difficulties and responsibilities.

\begin{tabular}{|c|c|c|}
\hline Year of Establishment & Percentage & Cumulative Percentage \\
\hline 1977 & 1.1 & 1.1 \\
\hline 1982 & 2.1 & 3.2 \\
\hline 1990 & 1.1 & 1.1 \\
\hline 1992 & 3.2 & 4.3 \\
\hline 1993 & 2.1 & 6.4 \\
\hline 1994 & 1.1 & 7.5 \\
\hline 1997 & 5.3 & 12.8 \\
\hline 1999 & 1.1 & 13.9 \\
\hline 2000 & 13.8 & 27.7 \\
\hline 2001 & 2.1 & 29.8 \\
\hline 2002 & 10.6 & 40.0 \\
\hline 2003 & 10.6 & 51.0 \\
\hline 2004 & 7.4 & 58.4 \\
\hline 2005 & 8.5 & 66.9 \\
\hline 2006 & 14.9 & 87.8 \\
\hline & 14.9 & 96.7 \\
\hline Total & $\mathbf{1 0 0}$ & \\
\hline
\end{tabular}

Table 1: Percentage distribution of women entrepreneurs by the year of the establishment of their enterprises;

Source: Bangladesh Women Chamber of Commerce and Industry (BWCCI) 2008, P: 19

During 1990s, government and non-government bodies have paid increasing attention to women entrepreneurs through formulation of various policies and programmes and introduction of new schemes and incentives. It adopted a multi-disciplinary approach for development of women entrepreneurs. Women entrepreneurs were given top priority for implementation of programmes under agricultural and its allied activities of diary farming, poultry, handicrafts and small scale industries, etc. Women were given priorities in all the sectors including small scale industries sector. In view of the need to bring the rural womenfolk in the development stream of the economy, the government, the NGOs and others related agencies have provided ample opportunities to promote entrepreneurial skill among women. As a result, the number of women entrepreneurs has increased over the years.

It is evident from the above data of the year of establishment of enterprises in the sample were established between the years 2000-2007. That indicating women are gradually interested in self employed business and entrepreneurial activities. It also indicating that women's visibility in economic sector is increasing.

\subsubsection{Nature of ownership}

Among 40 enterprises, $60.0 \%$ is owned by individual, $20 \%$ is jointly owned by family members and only $15 \%$ business is run in partnership with other members and others $5 \%$ are associated with team of various agency, club or organization. Partnership is also dominated by the traditional kinship relationships of women entrepreneurs have partnership with mother, with sisters, with brother, husband and friends. Domination of partnership by the kinship relationship can be explained by traditional patriarchal social values and social system, under which, women's social dealing with the people, particularly men, outside of the family is highly restricted.

\subsubsection{Types of business}

Structure of Women's Entrepreneurial activities depends on various types. The women have been found to participate in the following types of initiatives (Source FBCCI):

(1) Self-Employed: These women have acquired on their own, especially from parents, relatives or friends, the skills and capacities to operate enterprises. Some have under-gone training and apprenticeship or worked as skilled laborers and obtained enough knowledge to start their own business. Self-employed women are lesser in urban areas in comparison to rural areas where greater opportunities lie with the income generating activities of NGOs, which provide credit.

(2) Enterprise Ownership: These women, are the Owner/operators of existing micro-enterprises, and have proven management and technical skill in self-employment. They often wish to expand, upgrade or diversify their business through employment of family members as apprenticeship especially in the rural areas or engage 
and hire workers for the production when the business progresses in the urban areas. This is the popular structure in the urban areas, where market availability helps the women to develop their trade.

(3) Manufacturing: Women's traditional skill enable them to take up manufacturing in areas where raw material for the products is easily available. Women in these activities employ workers as skilled, non-skilled, permanent or as seasonal workers. With the expansion of business and the development of quality products, training in skill, technology, management and marketing becomes essential.

(4) Family Trade: Many women are involved in the family trades, hereditarily performed through generations and the skill is traditionally kept within the family. Women in such activities have their enterprises or employment based at homesteads. Manufacturing handicrafts or pottery, involved in food preparation, operating individual units of embroidery, tailoring printing, dyeing, weaving, spinning, net making, etc., are some of the activities in this structure. These women are helped by family members including males.

(5) Agricultural Activities: The rural women participate more in the agricultural sector, especially in operating vegetable gardens, horticulture production, nursery or even rice husking, and preparation of varied rice products. (6) Sub-Contracting: This new system of generating income in the non-formal sector is providing opportunities for women through a negotiable procedure obtaining orders for products from either, exporters, producers, whole sellers, and middlemen.

(7) Partners in Business/ Share holders/ Directors in Family Business Enterprises: Many of the women have become partners or share holders in larger business firms and industrial units. Some have entered the family industrial or business operations.

(8) Traders, Contractors, Order Suppliers, Business Executives: These new occupations have been mastered by the women even though they have to compete with the men. Though the women have to face tough competitions in these areas, it is remarkable to observe that they have proved themselves efficient in their dealings along with men and have succeeded in their endeavours.

(9) Medium and large Industry Owners: Women have become owners of medium and large industrial units either through inheritance or through private initiative. Many educated women are now the proud owners of shipping companies, tea gardens, trading centres, and advertisement firms.

(10) Women as exporters have ventured into exports directly by themselves or through other exporters. Export fairs, international trade fairs, single country fairs and initiative by importers have helped the women to produce quality products for exports.

Types of Production Units and Trades include the common small scale production units such as Handicrafts with various types of raw materials, Handloom Weaving \& Spinning, Basketary, Mat making, Manufacture of Coir products. Fishing Net making, Paddy husking by Dheki, Oil production by Ghani, Jute production and sale, Jute goods production. Pottery, Cane and bamboo products, Seri culture, Silk weaving, Honey Making, Screen print \& Batik, Embroidery, Dressmaking. Tailoring, Puffed Rice Making, Food production (packed or retail sale of dry food), Food Processing, Wood craft \& Furniture, Molasses making, Biri (indigenous cigarette made with special leaves) production, Milk production units, dairy and milk products, Dyeing and printing, Book Binding, Confectionery, Urea Molasses Block (cattle feed) etc., Nursery and Horticulture production.

Service industries and occupations: Restaurants, (production of snacks, meals, tea, confectionery) and Tailoring are now familiar professions both in the urban and the rural areas. Home-based shop-keeping is familiar in the rural areas. Non-Farm Activities: Cane product and jute carpet making, pigeon rearing for sale, petty trade especially with home-based shops, pond lease for fish cultivation and marketing, flower growing for sale to flower shops in the urban areas, fan and cap making. Small shop keeping, photocopy services, boutique shops, home-based garments making, painting and making of greeting cards, paper-bag making \& selling, selling of old tyres, fish and vegetable vending, soap vending, rice cake (pitha) making, road-side food selling shops are some of the urban non-farm activities observed. Innovative Products and New Areas: With the introduction of new technology, development of innovative ideas or even demand for new products, a variety of new areas have developed for women's entrepreneurship growth. These include, artificial flower making, production of straw caps and hats for export, printing of stationery and cards, vegetable dye products for dyeing and printing, patch-work quilt making, cotton spinning from waste garments, stuffed toys, decorative costume jewellery, manufacture of imitation jewellery even technology based business, for example Cyber café service in Chittagong city among the sample enterprise .

\subsubsection{Main sector of participation of women's entrepreneurs}

Among the sample respondents, majority of women entrepreneurs $70 \%$ were found to be involved in handicraft sector and then highest ratio of sector followed by garments or home textile $12.5 \%$, in Chittagong parlor business is popular among the respondents have $10 \%$. The table shows that women are becoming interested in nontraditional sectors like printing, IT based and food business. 
Promoting Women's Entrepreneurship through SME: Growth and Development in the context of

\begin{tabular}{|l|l|c|}
\hline \multicolumn{2}{|c|}{ Name of the Sector } & \% Enterprise \\
\hline 01 & Handicrafts & 70 \\
\hline 02 & Garments/Home Textile & 12.5 \\
\hline 03 & Parlor & 6.25 \\
\hline 04 & Food & 3.75 \\
\hline 05 & Agro Based & 2.5 \\
\hline 06 & Printing/Binding & 1.5 \\
\hline 07 & IT or technology based & 1.5 \\
\hline 08 & Others & 2 \\
\hline & Total & 100 \\
\hline
\end{tabular}

Table 2: Sector-wise business participation by women entrepreneur

\subsubsection{Sources of initial capital:}

The majority of the women entrepreneurs $72.5 \%$ managed their sources of initial capital from their own savings. Another important instance is the information of $15 \%$ women whose husbands provided them the initial capital. NGOs provided 5\% while the Government Agencies provided 3.5\% of such capital to the women. Others family members like father or mother provided $1.25 \%$ of the women. Both Public and Private Commercial Banks provided 2.5\% of the women, others managed their capital from Money lenders and managed their money through their inherited property and received their initial capital from other unspecified sources.

\subsubsection{Approaches to supporting organizations for SME development:}

Among the total respondents $15 \%$ of the respondents informed that they had approached Govt. organizations supporting SME development. The highest number of women entrepreneurs 37.5 utilized the SME services of Jatiya Mahila Sangstha (JMS) for their business purposes. BSCIC, Ministry of Women Affairs, SME Foundation, Export Promotion Bureau (EPB), Ministry of Industry, Bangladesh Parjatan Corporation (BPC), National Board of Revenue (NBR) and Business Promotion Council (BPC) and other NGOs were approached by $10 \%$ for the development of their business, information requirements, trade, technology and marketing necessities. So among the total respondents, $62.5 \%$ of respondent used the SME loan for their business purposes. Others respondents, they did know about or uninterested about any loan. With this data, micro credit has been extensively used in rural women entrepreneur development rather than urban area.

\subsubsection{Types of support received from different organizations for business development:}

The, highest support from Govt. Organizations was Financial support received by $14 \%$ women entrepreneurs, followed by Training by $13.3 \%$ women, Consultancy by $2.8 \%$ women. $0.1 \%$ received business training, credit facilities, donation, service certificates from the ministry and various suggestions for their business development. 1.1\% informed that they did not get any support. (Sources: MIDAS Report on Nov. 2009)

\subsubsection{Training \& human resources related issues:}

Among the respondents, $47.5 \%$ of the respondents informed that they had received training before starting their business (among 47.5\% of respondents, 30\% informed that they had received formal training from various institution and rest 17.5 of respondent had informal training like without any certificate), $27.5 \%$ received training during business time and $25 \%$ had not received any training. The highest number of training undergone by the women entrepreneurs $42.5 \%$ were in Handicrafts followed by training in Beauty parlour 15\%, Food making 3.75\%, Agro based (7.5\%) and IT training 2.5\%. Training on Business Development was taken by (7\%) women, followed by training on Agro-based activities such as Fishery by $3.9 \%$, Livestock by $3.0 \%$, and Nursery by $1.2 \%$. Food and Confectionery training was taken by $1.2 \%$ women entrepreneurs. Non traditional types of training included Design Development which was taken by $0.9 \%$ and Export Promotion by $0.2 \%$. $13.2 \%$ of the entrepreneurs took training on various other trades which helped them to promote their business and succeed in life as an entrepreneur. After formation of Chittagong Women Chamber of Commerce from 2001, they provided training on various category at free of cost. They also arranged training as short term courses to develop business skill without any fee for their registered members as well as non registered women entrepreneur.

\subsubsection{First impression of women entrepreneurs regarding receiving of bank loans:}

Private banks: Regarding first impression in receiving loans from private banks, the majority $47.5 \%$ of women entrepreneurs of sample in Chittagong expressed good impression, 22.5\% respondents have good on NGOs, $12.5 \%$ respondent have good impression on Govt. agency, $17.5 \%$ have good impression on Bangladesh Bank(BB) or SME foundation. Special Credit Programme - Bangladesh Bank/SME Foundation: Among the 
Promoting Women's Entrepreneurship through SME: Growth and Development in the context of

total respondents knowledge about the Bangladesh Bank (SEF) Program was known to only $40 \%$ of the respondents and $60 \%$ have not known about the circular. At present Banks were offering special facilities for SME loans and also for loans for women entrepreneurs.

\section{Participation In Trade Fair Of Women Entrepreneur}

Percentage distribution of the respondents by the status of their participation in trade fair Participation in trade fair is very important. It helped women to be exposed to diversified product, buyers and market demand. It also contributes to building market linkages. It is observed that in the SME sector, majority of the small enterprise owners participated in local, regional, seasonal, festival fairs and some in national trade fairs. Festival fairs were related to socio-cultural events and religious occasions. Rural melas were usually participated by the rural WE, who had products satisfying to the tastes of the rural buyers. The national trade fairs as the DITF (Dhaka International Trade Fair) and CITF (Chittagong International Trade Fair) organized by Export Promotion Bureau (EPB), was participated mainly by SMEs. In Chittagong, Chittagong Women Chamber of Commerce and Industry(CWCCI) also arranged trade fair as namely SME Expo Women's Fair from 2007 to promote and marketing the products of women entrepreneur. In international trade fair, the opportunity for women entrepreneurs to participate in trade fair seemed to be very limited. Among 40 women entrepreneurs, only $58.75 \%$ participated in trade fair. The rest of $41.25 \%$ did not have any opportunity to participate in any trade fair. Among 58.75 of respondents, who participated in trade fairs, $45.25 \%$ of them attended SME Expo Women's Fair, followed by International trade fair only $5 \%$ and local/village trade fair by 6.25 , in Chittagong division. Regarding satisfaction level of participation in trade fairs, $85 \%$ expressed that trade fairs contributed positively to building their capacity and highly promote their products in market.

It is observed that in the SME sector, majority of the small enterprise owners participated in SME Expo Fair, local, seasonal, festival fairs and some in international trade fairs. Festival fairs were related to sociocultural events and religious occasions. Rural melas were usually participated by the rural Women Entrepreneur, who had products satisfying to the tastes of the rural buyers.

\subsubsection{Status of Bangladesh Bank circular on refinancing scheme for SMEs to women entrepreneur and 2012 budget of Bangladesh}

Bangladesh Bank, the central bank of the country, developed a circular titled 'Refinancing Scheme for Women SME' and issued it to all scheduled banks and financial institutions on 7 February 2007. This circular adopted several important provisions for women SME including 10\% quota of its aggregate SME loan at 5-10\% interest rate and collateral free loan for women SME up to 1.5 million BDT15. In order to see the implementation status of this circular, the research tried to explore relevant information. It should be mentioned here that it was a landmark initiative undertaken by the central bank in order to facilitate women entrepreneurs to have access to finance but possibility of being benefited by the women entrepreneurs from this circular is also related with proper dissemination of information. The above figure shows that the level of dissemination of information about this circular is very poor, as $65 \%$ of the respondents did not know anything about this circular. Among 35\% of the respondents, who are informed of this circular, $79 \%$ of them got information from BWCCI through its various activities like seminars, trainings etc. Among informed respondents, $11 \%$ knew about this circular from the newspaper, 5\% from NGO and other community based organizations. Although $35 \%$ of the total respondents heard about the circular, 59\% of them did not know about all provisions of the circular. The information mentioned above shows that either Bangladesh Bank or any the banks did not take any effective mechanism to disseminate information of this circular o omen entrepreneurs or other stakeholders. Poor information dissemination process contributed to poor implementation of this circular. Bangladesh Bank circular (March 2008) introduced a refinancing scheme in the SME sector for women entrepreneurs. It invited banks and financing institutions to take advantage of the scheme in supporting women entrepreneurship development and instructed them to: (i) establish dedicated women entrepreneurs' desks; (ii) arrange training programs; and (iii) ensure the adequate dissemination of information on these facilities in each institution. . These areas include: (a) Ministry of Industry: review of the industrial policy to reserve industrial parks for women entrepreneurs in all divisional towns, establish a separate bank for women entrepreneurs and ensure collateral-free loans for women entrepreneurs; (b) Ministry of Commerce: review the export policy to make it gender-friendly; ensure 25\% quota for women entrepreneurs participation in international trade fairs, single exhibition of local products and other market promotion activities in foreign countries, and single country trade fair; (c) Ministry of Finance: remove or replace current guarantee requirements on commercial loans to women entrepreneurs; (d) Bangladesh Bank: (i) establish central and local monitoring bodies for financing of women entrepreneurs; (ii) restructure the boards of public sector banks to include at least $25 \%$ women representation; (iii) monitor and record lending operations on a sex-disaggregated basis; (d) implement the provision for collateral free access to finance from bank and other sources [Source: Women's National Business Agenda, BWCCI, 2009]. 
Promoting Women's Entrepreneurship through SME: Growth and Development in the context of

In this financial year of 2012 Budget Bangladesh government declared about special fund to develop women entrepreneur greatly. The government of Bangladesh emphasizes women development in the greater interest of the country," In national budget 2012-2013 government allocate Tk 1 billion as a special fund to promote the development of women entrepreneurs. BWCCI's request to release funds on the condition that the chamber develops a comprehensive plan on how the money will be used. This is really a great step by government to promote and development of women entrepreneur in our country but this will happen only when the fund will be used properly and with effective implementation plan by all the concerned govern body.

\section{Problems Regarding Women Entrepreneurship Development In Bangladesh}

7.1 Business related problems: Problems in business are various;

- Inadequacy of capital is still the main problem and where available the high interest rates discourage investment.

- Moreover, absences of marketing facilities for women are major obstacles to smoothly marketing or selling their products.

- As the male middlemen suppliers, contractors or wholesaler dominate industry in fact monopoly, wholesalers buy their goods at lower price on the other hand supplier charges higher. So in both sided women entrepreneurs have losses their business profit.

- Lack of opportunity for accessing to foreign market as women entrepreneur have produced exportable quality goods.

- The absence of proper sales centre or show room facility

- Non availability of skilled labor or trained employees

- Besides, products are sometimes put up for sale on credit basis creating problems in the collection of the money.

- Lack of improved implements and machinery, existing competition faced due to expansion of production, difficulty in the procurement of raw materials, problems of sales collection, problems increased by middlemen,

- Constraints in transportation and marketing are existing problems for business.

- Lack of proper training on management and production skill up-gradation

- Lack of healthy workplace environment and especially lack of training facilities are some of the major constraints which should be overcome for steady functioning of the business.

- Due to lack of market facilities women do not get the proper prices for their products, which are under priced by the customers or wholesalers who order their products.

\subsection{Social problems faced by women entrepreneur}

Social digress of women, especially in rural areas, arte common societal norm in our society. The normative values that restricted women entrepreneurs' mobility. This kind of pattern of societal behavior hinders women's open involvement in a variety of entrepreneurial fields. It is reported that, the women entrepreneurs operating in the rural areas even some of found in our sample areas are bounded by some social customs and strong religious barriers, creating difficulties in their operations. Women observing "purdah (seclusion) often find it difficulties to visit banks, purchase their inputs or raw materials or market their product in public settings where they would have deal with men. In view of this problem, it is somewhat difficult for the officials to perform their responsibilities smoothly, especially in dealing with women entrepreneurs working severe social constraints. (Rahman, Hossain and Miah, 2000).

Strong religious sanctions (especially guided by Molla who explain the religious principles differently) are creating difficulties for women entrepreneurs in operating their business. According to the family culture in Bangladesh women are socially neglected. Male members of the family always want to keep their wife in home so that they can rearing the their child only and they would not perform others activities like entrepreneurial or economic activities. Bangladeshi fundamentalists have physically attacked women that can be transgressed sexual norms Goswami, 1998). This problem have raised by the practicing of culture that creating hinders to the development of women entrepreneurship. Even sometime they did not get any support from their family members especially for married women. Women due to their physical stature often encounter 'masrtans (hoodlooms) rowdy males, whom they find hard to tackle and are stressed to pay money on demand (FBCCI Journal October 2001). Often entrepreneur often cheated by by their male partners in trade through unscrupulous means which may turn hazards when apt to encounter. They often suffer the indignities of sexual harassment by various parties that restricted their movements and damage the social security. 


\section{Policy Implications}

There is several policy implications for improving women entrepreneurship in Bangladesh are listed below:

\subsection{Actions of government}

- Commitment of the Government can flourish entrepreneurship development, but such commitment would require establishing some rural entrepreneurship development policies and rules.

- The functions of Directorate of Women's Affairs and the Directorate of Social Welfare in each district have to be focused to the needs and problems of rural women. They must make a complete list of all rural women running any activity on commercial banks within the district and complement their activities with basic information, training and education. They should carefully monitor their business operations run by their credit.

- The Government needs to be more proactive in monitoring credit operations of various NGOs through proper audit and control. Cheap credit should be ensured to promote rural women entrepreneurship.

- Special attentions should be given to promote income-generating programs in rural areas. Programs need to be taken to train and literate the rural entrepreneurs and make them socially ware. Both electronic and print media can be used to reate social awareness among rural population.

- Government needs to establish the rule of law by implementing the existing laws and create ethical code to gear up the active participation of people in economic development.

- Government should take necessary initiative to improve the infrastructure facilities such as communication electricity, utility services (Fuel, gas and water) etc. This will certainly help to improve the socio economic conditions of rural entrepreneurs.

- Government needs to be aware of market instability. Government agencies and the bank authority can help to extend the marketability of the goods produced by the entrepreneurs.

\subsection{Attitude toward women entrepreneurship}

- Social attitude towards the operation of women entrepreneurs needs to be changed. Sometimes rigid social norms, values and attitude act as barrier in rural women entrepreneurship development. Our patriarchal society always focuses on their physical beauty. Their inner beauty and talent is often ignored. In rural areas different NGO, banks and development organizations are working on women development by providing credit. They are working in order to change societal attitude towards women. Government and private organizations should come forward and take different awareness raising programs in order to change societal attitude towards women. Overall culture should be removed. In this respect necessary steps needs to be taken by the field workers.

- Entrepreneurship courses should be introduced in both formal and informal educational institutions in Bangladesh so that unprivileged women are exposed to possibilities of job creators instead of job seekers. It will empower women with entrepreneurship skill. More practical and need oriented training program should be designed for entrepreneurs.

\subsection{Financial and Bank-related Policy Recommendations}

- Banks should make the list of genuine and potential entrepreneurs in both rural and city area. After the identification the support and sustaining services must be extended to them for desired growth of rural entrepreneurship.

- Women entrepreneur should be provided collateral free loan as they have no ore littlie assets. The margin of security should also be liberalized.

- The procedures of sanctioning loan should be simplified and loan application must be appraised as early as possible.

- The rate of interest for loans to working capital should be reduced and rebate should be allowed to encourage timely return of loan.

- Bank loan policy should be linked with industrial policy of the country. There should be an allocation of fund in the loan portfolio of banks to supplement the Government development plan and industrial policy. Coordination is also required for proper allocation and distribution of fund to rural entrepreneurs.

- Long term loan should be available

- Banks should maintain facilities for easy access of women within bank premises. The volume of works in each bank branch and women service desk has been gradually increasing. This will help them render effective services for entrepreneurship development.

- An investment bank for women should bee established.

- One stop services should be created in the commerce ministry exclusively for the women entrepreneurs for facilitating investment and business. 
Promoting Women's Entrepreneurship through SME: Growth and Development in the context of

- Women entrepreneur should have direct access to finance and other infrastructure and institutional facilities.

- Setting up a special window with the Bangladesh Bank would work effectively and could resolve this problem.

- Pre and post investment counseling for women entrepreneurs for credit

- Establishing credit guarantee scheme for women entrepreneurs

- Preferential treatment of the women entrepreneurs by credit in trust sector.

- Maintaining gender based data on credit disbursement an dissemination of information on credit opportunities

\subsection{Institutional services policy}

- Trade License requirement and TIN certificate procedure should be simplified.

- Concerned Chamber of Commerce and Industry should be open separate window for facilitating

- Export Promotion Bureau should be so activated that it becomes helpful for women entrepreneurs.

- Government should establish an information centre for women entrepreneur so that they can get easily the needed information related with their business.

- Establishing strong network among different institutions and agencies involved in the development of the women in general and sharing their experiences.

\subsection{Training related policy implication}

- Effective Training programs are needed for women entrepreneurs' development. Most of the women entrepreneurs use traditional manual training and skills in their business. Technology based training can play a role in increasing productivity, increasing the quality of output and saving time and money of women entrepreneur. Training should be given to women entrepreneurs so that they can use technology effectively.

- Women entrepreneur need to up-to-date training for new products development, better management of the undertaking and improving the quality of products and services.

- Women entrepreneurs have littlie designing skills; they need good and marketable designing training, which should be organized by government and others supportive institutions like CWCCI.

\subsection{Management and marketing related policy}

- Arrange management skill upgrading training for women entrepreneurs.

- Provide consultancy services to the women entrepreneur to develop their business skill regular basis.

- Arrange display centre at national and international level for displaying and distributing the products of women entrepreneurs

- Supporting and ensuring the participation of the women entrepreneurs in national and international trade fairs.

\subsection{Abolish social discrimination and measure women contribution}

- In Bangladesh, gender discrimination is mostly affected, for that reason even parents gives more value to the work and development to their son not to the development of daughter. Here, the social awareness program can be eliminated this discrimination.

- Inheritance law of the country should be reformed so that women have access to resources and collateral for credit.

- Government and other local agency should take step to reduce the social constrains like various customs related to women life structure, religious constraints, eve teasing and family torturing.

- Government should ensure the secured environment for women entrepreneur and for whole female.

\section{Concluding Remarks}

Entrepreneurship plays a vital role in economic development and industrial growth of a country. Whereas the nearly fifty percent of total population is female, so it is obviously necessary to develop the women entrepreneurship for the achievement of economic development of the nation. Bangladesh is in such position and the growth of women entrepreneurship has risen greatly for some couple of years. Here the SME is play a vital role to be development of the entrepreneurship. Though the women entrepreneur face many problems as financial or credit facility, bank loan, training facility, marketing problems, social security problem and attitude toward women of their family and society is also create problems to develop themselves as entrepreneur. Our government has adopted some policies regarding women entrepreneurship development but due to administrative complication all these policies may fail at the time of implication. Some others semi autonomous organization and NGOs are working for women entrepreneurship development in Bangladesh by providing training facility and others supportive business and marketing facility. But the SME loan, financial factors and 
other business procedure mostly related with governmental body and their implication policy. In Bangladesh, now women are educated and interesting about establish their own business according to the study. So therefore, the extended SME program can facilitate them by providing collateral free and easy access of financing their business. So here the governments rules, policies regarding business set up and bank related regulation can be adopt effectively and rules and policy formation should always support the women entrepreneur. So that the women entrepreneur can develop themselves and could be performing to the development of country's sustainable economic growth as well as make contribution for their family and modern society.

\section{References}

[1] Afrin, Sharmina; Nazrul Islam; and Shahid Uddin Ahmed (2008) “A Multivariate Model of Micro Credit and Rural Women Entrepreneurship Development in Bangladesh”, International Journal of Business and Management, Vol. 3, No. 8 (August), pp. 169-185.

[2] ADB project Report Sep 2009; Promoting Women's Entrepreneurship in Bangladesh.

[3] Akram, "Funds are a major issue for women entrepreneurs", Daily Times, 30 December 1999.

[4] Aktaruddin, M. (1999) "A Case Study of Some Successful and Unsuccessful Entrepreneurs in Bangladesh", Journal of Business Administration, Vol.25, pp. 89-126.

[5] Aktaruddin, M. (2000) "Socio-Economic Profile of Industrial Entrepreneurs: A Study on North Region of Bangladesh", A Journal of Banking and Finance, Vol. 25, pp. 39-53.

[6] BBS, The Statistical Pocket of Book of Bangladesh, Dhaka, 20065.

[7] Begum, R. (1993) "Entrepreneurship in Small-scale Industry: A Case Study of Engineering Units", Dhaka University Journal of Business Studies, Vol.14, pp. 159-162.

[8] BWCCI, Quarterly Progress Report of Promoting Women Entrepreneurship through Advocacy Project, quarter-1,2, 3, 4 (phase-1), $5,6,7$ (phase-2).

[9] Dhaka Chamber of Commerce and Industry (DCCI) (undated) "Women Entrepreneurs in Bangladesh", Dhaka: Dhaka Chamber of Commerce and Industry (DCCI), DCCICIPE/ ERRA project, Economic Policy Papers (EPPs), No. 21; available at: www.dhakachamber.com/cipe/EPPs percent20\& percent20Studies/WEDfff.pdf.

[10] Goswami, Arun Kumar (1998) "Empowerment of Women in Bangladesh", Empowerment: A Journal of Women for Women, Vol. 5, p. 45.

[11] Hossain, K. S. and M. Rahman (1999) "Role of Grameen Bank in Entrepreneurship Development: A Study on Some Selected Entrepreneurs", Islamic University Studies (Part C), Vol. 2, pp 7-13.

[12] Habibullah, M. (1987) "Entrepreneurship Training and Development”, Chittagong: Chittagong University, Faculty of Commerce, Bureau of Business Research, pp. 47-58. Habibur Rahman, A. H. M. (1995) "Bank Credit for Women Entrepreneurship Development in Bangladesh", Bank Parikrama, Vol. 20, p. 67.

[13] Habibur Rahman, A. H. M.; Muhammad Ali Mian; Durgadas Bhattacharjee; and Azizur Rahman Khan (1979) Entrepreneurship and Small Enterprise Development in Bangladesh (Dhaka: University of Dhaka, Bureau of Business Research).

[14] Haidar, Rumel and Rasheda Akhtar (1990) "The Role of NGO and Women's Perception of Empowerment: An Anthropological Study in a Village", Empowerment, Vol. 6, pp. 61-62.

[15] Hossain, K. S. and M. Rahman (1999) "Role of Grameen Bank in Entrepreneurship Development: A Study on Some Selected Entrepreneurs", Islamic University Studies (Part C), Vol. 2, pp 7-13.

[16] Huda, A Comparative Study of Women Entrepreneurs in Formal and Informal Economy: A Study of Dhaka City, Asian Journal of Business Management 1(1): 19-23, 2009 ISSN: 2041-8752

[17] Islam, M. (2003) "Rural Entrepreneurship in Bangladesh: A Study of Bangladesh Krishi Bank", Rajshahi: Rajshahi University, Department of Accounting, Ph.D. Thesis.

[18] Islam, Saiful Md. and Md. Aktaruzzaman (2001) "The Problems of Rural Women Entrepreneurs in Bangladesh: A Case Study of Jhenaidah District”, Islamic University Studies (Part-C), Vol. 4, No. 1, p. 19.

[19] Khanka, S. S. (2002) Entrepreneurial Development (New Delhi, India: S. Chand Group). Luthans, Fred (2005) Organizational Behaviour (New York: McGraw-Hill, 10th edition). Momen, Md. Nurul and Mst. Marzina Begum (2006) "Impact of Micro Credit Program for Women Development in Bangladesh: A Case Study of BRAC”, Asian Journal of Information Technology, Vol. 5, No. 11, pp 1269-1283; available at: www.medwelljournals.com/fulltext/ajit/2006/1269-1283.pdf.

[20] Rahman, Aminur (1999) Women and Microcredit in Rural Bangladesh - An Anthropological Study of Grameen Bank Lending (Boulder, CO: Westview Press).

[21] Rahman, Mizanoor Md; Ibrahim Md. Hossain; and Abdus Shahid Miah (2000) "Problems of Women Entrepreneurship Development: A Study of Grameen Bank Finance on Some Selected Areas", Islamic University Studies (Part-C), Vol. 3, pp. 124128.

[22] Rotaru, Cornelia (2009) "Case Study: The Bangladesh Women Chamber of Commerce and Industry", in: Eric Hontz (ed.) Women's Business Associations Experiences from around the World: South Asia (Washington, DC: Center for International Private Enterprise (CIPE)), pp. 15-25; available at: www.cipe.org/publications/papers/pdf/South percent20Asia percent20Chapter.pdf.

[23] Saleh, Abu (1995) “A Profile of the Women Entrepreneurship in Bangladesh", Journal of Business Studies (of Dhaka University), Vol. 16, No.1 (June), pp, 159-170. Scott, W. Richard (2001) Institutions and Organizations (Thousand Oak, CA: Sage Publications).

[24] Shehabuddin, R. (1992) Empowering Rural Women: The Impact of Grameen Bank in Bangladesh (Dhaka: Grameen Bank).

[25] United Nations (1995) Fourth World Conference on Women, Beijing, China - September 1995, Action for Equality, Development and Peace, Platform for Action (New York: United Nations, Department of Economic and Social Affairs, Division for the Advancement of Women); available at: www.un.org/womenwatch/daw/beijing/platform/.

[26] United Nations Convention on the Elimination of All Forms of Discrimination against Women (CEDAW) (2003) "Consideration of reports submitted by States parties under article 18 of the Convention on the Elimination of All Forms of Discrimination against Women" -- Fifth periodic report of States parties: Bangladesh (New York: CEDAW, Report No. CEDAW/C/BGD/5) 
Appendix: 1

Questionnaire

1. What type of business you have operated?-----

2. From when you started you business?

3. How you have collected the initial fund to start your business?

a. SME Loan b) Finance by Husband c) Own Savings d) Loan from others

4. Did you take SME loan to operate the business?

$$
\text { * Yes *NO }
$$

5. Did you take loan from any bank / micro credit loan from any NGO?
*Yes
$* \mathrm{NO}$

6. Is the interest rate of is justified / over rate?
*Justified
*Over rate

7. Did you keep mortgage anything for taking the loan?

* Yes *No

8. Are you satisfied with the SME service or bank service?
* Satisfied
*Not Satisfied
*Average

9. Did you know the circular of Bangladesh Bank about SME Scheme?

*Yes *NO

10. Did you participate in any trade fair?

$$
\text { *Yes *NO }
$$

11. What type of trade fair was it?

a) International trade fair b) Local Fair c) Specially for Women entrepreneur d) All of these.

12. What do you think about trade fair that gave any facility to grow your business? 